\title{
Dzieje poznańskiej immunologii
}

\section{Historical context of Poznań immunology}

\author{
Jan Żeromski
}

\begin{abstract}
Poznań
Streszczenie: Poznań jest ważnym i dużym ośrodkiem naukowym na mapie Polski, a nauki medyczne są istotną jego częścią. Wśród nich immunologia, nauka o odporności, jedna z najmłodszych dyscyplin medycznych rozwinęła się w mieście nad Wartą wyjątkowo wcześnie, szybko i pomyślnie. Niemal w każdym szpitalu akademickim, w różnych zakładach, w placówkach Polskiej Akademii Nauk już w latach sześćdziesiątych ubiegłego wieku gromadzili się i dyskutowali miłośnicy immunologii. Powstawały pracownie i zakłady związane z tą dziedziną wiedzy. Poznańscy immunolodzy współtworzyli Polskie Towarzystwo Immunologiczne (PTI) i aż 4 Poznaniaków pełniło później funkcję Prezesa tego Towarzystwa. Wyrazem uznania dla poznańskiej immunologii było powierzenie Polsce organizacji Europejskiego Spotkania Immunologów (EFIS 2000) właśnie w Poznaniu. Tu powstała, chyba pierwsza w kraju katedra immunologii klinicznej w ówczesnej Akademii Medycznej. Dorobek naukowy poznańskich immunologów jest wartościowy i bogaty. Obejmuje szereg ważnych osiagnięć, zwłaszcza w zakresie immunologii klinicznej, jak wytworzenie szczepionki dla leczenia czerniaka, powstanie immunologii rozrodu czy wykazanie roli odporności miejscowej w patogenezie procesu nowotworowego u ludzi.
\end{abstract}

Summary: The city of Poznan is a large and important science centre on the map of Poland. Medical sciences constitute its significant portion. Among them immunology belongs to the most novel medical disciplines. It fostered here, in the town upon the river of Varta, exceptionally fast and efficiently. Almost in each academic hospital, in the local facilities of the Polish Academy of Sciences, already in the 1960s there were formed discussion groups of enthusiasts of immunology. Some laboratories were soon established and subsequent departments devoted to this field. Poznan immunologists participated in the establishment of the Polish Society for Immunology about 1963. It is worth to mention, that in the following years four Poznan immunologists have been granted the honor of the President of Polish Society. Poznan immunology centre became internationally recognised, what resulted in entrusting the Polish Society organisation of 14th European Immunology Meeting (EFIS 2000) just in Poznań City. Scientific achievements of Poznan immunologists are reflected in several areas, predominantly in the field of clinical immunology such as the production of anti melanoma vaccine, progress in immunology of reproduction, studies of tumor local immunity and, in particular of tumor microenvironment in human cancer.

Słowa kluczowe: historia immunologii, Polskie Towarzystwo Immunologiczne, poznańscy immunolodzy

Keywords: history of immunology, Polish Society for Immunology, Poznan immunologists 


\section{Wstęp}

Wśród wielu dyscyplin i specjalności medycznych immunologia należy do najmłodszych. Jest „dzieckiem”, o którym wielu poważnych i szacownych luminarzy medycyny albo w ogóle nie słyszało, lub tak i owszem, ale z przymrużeniem oka i z lekceważeniem. Tymczasem to "dziecko" wydoroślało i ku przerażeniu starszych medyków, nie tylko nie daje się zamknać w laboratorium, ale wkracza na oddziały szpitalne. Mało tego, zaczyna odbierać „,chleb” różnym doświadczonym klinicystom, bo kreuje specjalistów immunologii klinicznej, którzy zabierają się do leczenia chorych! Tego już za wiele dla szeregowego lekarza posiadającego jedna z wielu głównych specjalizacji, jak interna czy pediatria. Stąd, niejeden z nich „dorabia" sobie immunologię kliniczna jako dodatkowa specjalność. Nie powstrzymuje to jednak dalszego rozprzestrzeniania się immunologii w medycynie, niemal jak epidemii choroby zakaźnej. W szybkim tempie powstaja pochodne specjalności immunologii, jak alergologia, transplantologia, immunologia nowotworów, neuroimmunologia etc, etc. W chorobach wewnętrznych niemal każda odrębność narządowa ma swój odpowiednik immunologiczny niekoniecznie oparty na pojęciu nozologicznym, ale na diagnostyce, patogenezie a także, coraz częściej - terapii (vide reumatologia).

Ten trend nie ominął także naszego kraju. W poszczególnych ośrodkach akademickich miał on swoje różne uwarunkowania i odrębności. Dużą rolę w powstaniu i rozwoju immunologii polskiej jako odrębnej dyscypliny odegrał ośrodek poznański. Wydawało mi się, że warto prześledzić te minione lata powstawania i rozwoju immunologii na naszym terenie, choćby ze względu na sumę doświadczeń i błędów organizacyjnych mogących być wskazówką dla innych rodzących się dyscyplin, a także na osiagnięcia wielu zaangażowanych ludzi, które nie powinny być zapomniane. Podjałem więc próbę spisania znanych mi faktów i wydarzeń, bo należę do tych nielicznych, którzy w tym uczestniczyli i jeszcze żyja, dużo widzieli i pamiętaja. Za pomyłki, przeinaczenia czy pominięcia niektórych zasłużonych osób., choćby z powodu niewiedzy lub zapomnienia z góry przepraszam!

\section{Szpital Miejski im. Józefa Strusia, ul. Szkolna}

W latach pięćdziesiatych ubiegłego wieku na Oddziale Chorób Wewnętrznych tego szpitala zebrało się grono ludzi zainteresowanych immunologia, którzy później tworzyli jej zręby na poziomie ogólnopolskim. Byli to doktorzy: Stefan Mackiewicz, Kazimierz Burchardt, Irena Zimmerman-Górska, Urszula Michajlukowa, Władysław Fenrych i inni. W laboratorium Oddziału pod przewodnictwem Władka Fenrycha opracowano i wprowadzono do diagnostyki klinicznej pierwsze metody immunochemiczne, jak immunoelektroforeza i inne techniki żelowe. Na zebraniach klinicznych Oddziału, a później III Kliniki Chorób Wewnętrznych, pod kierownictwem prof. Franciszka Łabendzińskiego pojawiły się doniesienia i wykłady wprowadzające w zagadnienia ówczesnej immunologii. Dr S. Mackiewicz habilitował się w oparciu 
o warsztat immunochemiczny. W powstałej później i kierowanej przez niego Klinice Reumatologii powstała Pracownia Immunologii, w której wprowadzono kolejne testy immunologiczne dla potrzeb diagnostyki chorych. Gdy powstawało na bazie Instytutu Immunologii i Terapii Doświadczalnej Polskiej Akademii Nauk Polskie Towarzystwo Immunologiczne w 1960 roku, prezesem Towarzystwa został dyrektor Instytutu prof. Stefan Ślopek, a prof. S. Mackiewicz - wiceprezesem. Zaczęto wydawać w Poznaniu organ Towarzystwa - „Immunologię Polską". Jej redaktorem naczelnym została wybrana bliska współpracowniczka profesora Mackiewicza, docent Irena Zimmermann-Górska, która świetnie prowadziła przez wiele lat to czasopismo sponsorowane przez Polską Akademię Nauk.

\section{Zakład Anatomii Patologicznej AM}

Dwaj kolejni kierownicy tego Zakładu a później Katedry Patomorfologii, profesorzy Janusz Groniowski oraz Przemysław Gabryel, wcześnie dostrzegli potrzebę i rozumieli znaczenie immunologii we współczesnej medycynie. Dawali też zielone światło dla jej rozwoju w Zakładzie. Prof. Groniowski wysłał mnie, młodego asystenta Zakładu, do Warszawy na miesięczne przeszkolenie w tamtejszym Zakładzie Anatomii Patologicznej AM, gdzie funkcjonowała już znakomita Pracownia Immunopatologii pod kierownictwem dwóch wybitnych lekarzy po długoterminowych stażach w USA, doktorów Adama Nowosławskiego i Witolda Brzosko. Był to dla mnie niezwykle wartościowy okres pobytu. Zdobyłem praktyczne podstawy różnych technik immunologicznych a zwłaszcza immunofluorescencji, uczestniczyłem w ciekawych dyskusjach nie tylko naukowych, poznałem i zaprzyjaźniłem się z wieloma kolegami warszawskimi, a z niektórymi ta przyjaźń trwa do dziś, jak np. z prof. Kazimierzem Madalińskim. Nic więc dziwnego, że po powrocie z Warszawy postanowiłem stworzyć choćby mała pracownię immunologii w rodzimym Zakładzie. Przy poparciu prof. Groniowskiego okazało się to możliwe w pomieszczeniach ówczesnej Pracowni Histochemii. Zaczęliśmy od oznaczania przeciwciał przeciwjądrowych (ANA) w surowicy chorych z podejrzeniem tocznia układowego na osadach ludzkich granulocytów krwi obwodowej. Przywiozłem trochę odczynników znakowanych fluoresceina, dodatnie surowice ANA+ podarowane mi przez kolegów warszawskich, skromny mikroskop fluorescencyjny był dosteppny w Zakładzie, co pozwoliło na oznaczanie ANA u chorych. Było duże zapotrzebowanie na te badania, bo wówczas nikt ich nie oznaczał w Poznaniu. Mieliśmy nawet surowice do badania z innych miast od pacjentów, którzy trafili do kliniki prof. S. Mackiewicza. Między innymi, potwierdziliśmy podejrzenie autoimmunizacyjnej choroby watroby (lupoid hepatitis) u znanego polityka, działacza Polskiego Stronnictwa Ludowego.

Drugim asystentem Zakładu zainteresowanym immunologia okazał się, po stażu w szwedzkim laboratorium, dr Jan Bręborowicz. W swojej pracowni wprowadził szereg technik immunochemicznych i następnie zajał się ilościowym oznaczaniem w surowicy chorych antygenów płodowo-nowotworowych a zwłaszcza CEA i AFP, 
przy pomocy czułych metod radioimmunologicznych (RIA). Zanim wprowadzono komercyjne testy RIA, była to jedna z nielicznych możliwości oceny wyżej wymienionych antygenów w Polsce. Ich oznaczanie miało i ma istotne znaczenie dla diagnostyki i rokowania w często występujących nowotworach złośliwych, jak rak jelita grubego, raki płuc i piersi. Stąd wśród pacjentów dr Bręborowicza były osoby powszechnie znane, często $\mathrm{z}$ pierwszych stron gazet, $\mathrm{z}$ radia i telewizji, co najlepiej świadczy o jakości i renomie tych badań.

W latach siedemdziesiatych ubiegłego wieku, z inicjatywy kierownika Zakładu Biologii i Parazytologii AM prof. Czesława Gerwela oraz naszego szefa prof. Gabryela powstał zespół uczelniany, złożony z Zakładu Biologii, Kliniki Chorób Pasożytniczych i naszego Zakładu, do spraw biologii, immunologii i kliniki włośnicy. Choroba ta była wtedy stosunkowo częsta w Polsce, zdarzały się ogniska zachorowania obejmujące kilkadziesiąt osób po spożyciu zakażonego mięsa. Prof. Gerwel, wybitny ekspert zagadnienia w skali międzynarodowej, uzyskał na te badania środki finansowe od rządu USA. Moja Pracownia Immunologii została włączona w ten projekt badawczy razem z Pracownią Histochemii kierowana przez dr biol. Leokadią Gustowską. Pracowaliśmy głównie na materiale doświadczalnym szczurów. Uzyskaliśmy wiele ciekawych wyników prezentowanych na licznych zjazdach krajowych i międzynarodowych a także w publikacjach o obiegu światowym.

\section{Państwowy Szpital Kliniczny nr 2, ul. Przybyszewskiego 49}

Zainteresowanie immunologia w dużym (ponad 1000 łóżek) szpitalu klinicznym, na terenie którego w Zakładzie Patomorfologii mieściła się pracownia a później Zakład Immunopatologii, wyraziło się $\mathrm{w}$ powstaniu małych ośrodków badawczo-diagnostycznych w poszczególnych klinikach. W Klinice Endokrynologii prof. Jerzy Kosowicz stworzył silną grupę zajmującą się nowoczesną immunodiagnostyką i patogenezą chorób autoimmunizacyjnych gruczołów dokrewnych. Opracowane tam metody radioimmunologiczne (RIA) były publikowane w czasopismach immunologicznych o światowym zasięgu ${ }^{1}$. Grupa ta wykazała rolę sprawczą enzymu 21-hydroksylazy w chorobie Addisona ${ }^{2}$.

W Katedrze i Klinice Neurologii pod przewodnictwem prof. Mieczysława Wendera a obecnie prof. Jacka Losego prowadzono badania poznawcze i immunodiagnostyczne dotyczace stwardnienia rozsianego (sclerosis multiplex). Docent tej Katedry, Sławomir Michalak, wdrożył i dalej rozwija nowoczesną immunodiagnostykę neuropatii nowotworowych. W Klinice Nefrologii poczatkowo śp. prof. Maciej Krzymański a później dr, a obecnie profesor, Zofia Niemir wprowadzili nowoczesne metody oceny

1 J. Kosowicz, M. Gryczyńska, G. F. Botazzo, A radioimmunoassay for the detection of adrenal antibodies, “Clin Exp Immunol" 1986, 63, s. 671-679.

2 A. Baumann-Antczak, N. Wedlock, J. Bednarek J et al., Autoimmune Addison disease and 21-hydroxylase, "Lancet" 1992, II, s. 439-440. 
funkcji nerek oparte na immunologii i biologii molekularnej. W Klinice Dermatologii śp. prof. Wojciech Silny a następnie doc. Marian Dmochowski unowocześnili immunodiagnostykę schorzeń skóry a zwłaszcza chorób pęcherzowych ${ }^{3}$. O zainteresowaniu immunologią w Szpitalu Klinicznym nr 2 świadczy fakt, że kilkunastu lekarzy z tego szpitala przygotowało i obroniło rozprawy habilitacyjne merytorycznie zwiazane $\mathrm{z}$ immunologia. Byłem recenzentem pięciu z nich.

W Zakładzie Immunopatologii, oprócz oznaczeń autoprzeciwciał, rozwinęła się natomiast diagnostyka białaczek i chłoniaków przy pomocy cytometrii przepływowej. Byliśmy chyba pierwsza jednostką organizacyjna w Poznaniu, która uzyskała potrzebna aparaturę dla tej metodologii. Dwaj moi wychowankowie, dr Grzegorz Dworacki (obecnie dr hab. prof. UM) i dr Jan Sikora (obecnie profesor), stworzyli duet diagnostyczny dla wyżej wymienionych nowotworów o zasięgu znacznie przekraczajaccym granice Wielkopolski. Dr Dworacki uzyskał niezbędna ",know how" tej, techniki po długoterminowym pobycie w Pittsburgu (USA) w laboratorium mojej przyjaciółki prof. Teresy Whiteside.

\section{Wojewódzkie Centrum Onkologii (WCO)}

Na terenie Centrum powstał Zakład Immunologii Nowotworów prowadzony przez dr Andrzeja Mackiewicza. Zakład rozwinął się w dużą jednostkę organizacyjna, liczącą obecnie ponad 20 pracowników, świetnie wyposażoną w sprzęt i aparaturę, Głównym przedmiotem zainteresowania tego Zakładu były próby immunoterapii czerniaka złośliwego przy pomocy wytworzonej i przebadanej uprzednio szczepionki. Wyniki leczenia zastosowane już u dużej liczby chorych są obiecujące ale wymagają weryfikacji czasowej i porównania z innymi metodami terapeutycznymi współczesnej onkologii.

\section{Zakład Patofizjologii Akademii Medycznej}

W latach siedemdziesiątych ubiegłego wieku zebrało się w tym Zakładzie pod patronatem ówczesnego kierownika prof. Antoniego Horsta grono młodych zainteresowanych immunologia podstawową. Prym wśród nich wodził dr Jan Jaroszewski, adiunkt Zakładu, obdarzony charyzmą i mający oryginalne pomysły i idee naukowe. Sprzyjało to gromadzeniu w Zakładzie wartościowych osób, w tym również studentów medycyny, wśród których warto wymienić późniejszych profesorów jak: Jerzy Nowak, Maciej Kurpisz, Krzysztof Wiktorowicz, Zygmunt Przybylski czy Ryszard Słomski. Dzięki kontaktom z ośrodkami zagranicznymi

3 M. Dmochowski, T. Hashimoto, B. S. Bhogal et al., Immunoblotting studies of linear IgA disease, "J Dermatol Sci" 1993a, 6, s. 194-200. 
grupa ta opracowała i wdrożyła jako pierwsza w Polsce technologię ilościowego oznaczania limfocytów T i B we krwi obwodowej, którą przekazała kilkudziesięciu osobom szkolącym się w Zakładzie z całego kraju. Jan Jaroszewski utworzył klub dyskusyjny dotyczący współczesnej immunologii, prowadzony wyłącznie w języku angielskim, co było ewenementem $w$ tamtych czasach. Posypały się doktoraty wśród młodych a dr Jerzy Nowak przygotował i obronił przed Rada Wydziału Lekarskiego poznańskiej AM rozprawę habilitacyjną dotycząca pochodzenia receptora Fc immunoglobuliny G, której miałem zaszczyt być recenzentem. Dr Jan Jaroszewski, mający wyjątkowo duży potencjał intelektualny, stworzył oryginalną teorię pochodzenia i regulacji odpowiedzi immunologicznej. Opublikował to w czasopiśmie naukowym, jednak o stosunkowo wąskim obiegu. Warto tu dodać, że badacz dunski KJ Jerne za podobną teorię dotyczącą układu idiotypów i sieci idiotypowej, opublikowana w znanym czasopiśmie o zasięgu światowym, otrzymał w 1974 roku nagrodę Nobla!

\section{Instytut Genetyki Człowieka Polskiej Akademii Nauk}

Prof. A. Horst stworzył całkowicie odrębny lokalowo, początkowo Zakład, a następnie Instytut Genetyki Człowieka PAN. Do tej nowej jednostki organizacyjnej przenieśli się z Zakładu Patofizjologii AM dr Jerzy Nowak i dr Maciej Kurpisz. Pierwszy zorganizował tam pracownię a później Zakład Immunogenetyki i był prekursorem tej dziedziny immunologii na gruncie poznańskim. Był następca prof. Horsta i przez wiele lat pełnił funkcję dyrektora Instytutu Genetyki Człowieka PAN. Dr Maciej Kurpisz zainspirowany problemem związków gamet z układem odpornościowym, jeszcze przez dr J. Jaroszewskiego w Zakładzie Patofizjologii AM, zorganizował Zakład Immunologii Rozrodu. Nie tylko utworzył nowy kierunek w immunologii polskiej - immunologię rozrodu, ale stał się jego popularyzatorem w Polsce i na świecie. Organizował Szkoły Immunologii Rozrodu w kraju i zagranica $(n=3)$. Działał aktywnie na forum międzynarodowym współtworzacc, a później kierując, ESRADI (European Society for Reproductive and Developmental Immunology i następnie ESRI (European Society for Reproductive Immunology), był współorganizatorem światowych kongresów tej specjalności. W kraju wprowadził diagnostykę molekularną niepłodności na tle immunologicznym.

\section{Klinika Chorób Zakaźnych}

Powiązania immunologii z teorią i praktyką chorób zakaźnych nie wymagają komentarza. Pomimo fatalnych warunków lokalowych Kliniki w starym budynku na Zawadach, stosunkowo wcześnie powstała tam Pracownia Immunologii. Przewinęło się przez nią wiele osób o znanych dziś nazwiskach i tytułach (doktorzy, a z czasem profesorzy: Andrzej Szkaradkiewicz, Jacek Juszczyk, Witold Kiczka, Andrzej Mackiewicz i inni). Opracowany w niej immunologiczny warsztat badawczy dotyczący zarówno 
odpowiedzi humoralnej jak i komórkowej in vitro, okazał się niezwykle przydatny w okresie terapii wyciagiem grasicy -TFX (Thymus Factor X) chorych na wirusowe zapalenia watroby $y^{4}$ Wykazano wtedy korzystny immunomodulacyjny wpływ tego preparatu u chorych jak skrócenie czasu hospitalizacji, zmniejszenie odczynu zapalno-martwiczego w utkaniu histologicznym wattroby a także poprawę ich parametrów biochemicznych jak spadek aktywności bilirubiny, enzymów watrobowych ALT i AST a także zanik antygenu HBsAg u 4\% pacjentów po roku terapii ${ }^{5}$. Przedmiotem badań były także zjawiska autoimmunizacyjne. Wykazano np. częste $(67 \%)$ występowanie czynnika reumatoidalnego $\mathrm{w}$ surowicy chorych $\mathrm{w}$ ostrych wirusowych zapaleniach watroby. Ewenementem w skali ogólnopolskiej była publikacja dotycząca opisu tzw. toczniowego zapalenia watroby (lupoid hepatitis) będąca pierwszą $\mathrm{w}$ polskim piśmiennictwie medycznym ${ }^{6}$.

\section{Klinika Chorób Wewnętrznych (Państwowy Szpital Kliniczny nr 1, ul. Długa 1/2)}

Z inicjatywy dr Michała Wierzchowieckiego w późnych latach sześćdziesiątych ubiegłego wieku, powstała na bazie tej Kliniki Pracownia Immunologii Klinicznej. Wdrożono w niej nowatorskie, jak na owe czasy, metody badania zjawisk autoimmunizacyjnych $\mathrm{w}$ chorobach wewnętrznych, a zwłaszcza reumatycznych, $\mathrm{w}$ wirusowych zapaleniach wątroby i innych, oparte na oznaczaniu różnego rodzaju autoprzeciwciał. Przedmiotem głównego zainteresowania zespołu Pracowni były aspekty diagnostyczne i patogenetyczne tocznia układowego. Wyniki tych badań publikowane w prestiżowych czasopismach naukowych wzbudziły zainteresowanie w kraju i zagranica, czego wyrazem było zaproszenie dr Michała Wierzchowieckiego do University of Southern California, Los Angeles, czołowego ośrodka zajmującego się chorymi z toczniem układowym.

\section{Wydarzenia i sprawy organizacyjne}

W 1970 roku odbył się w Waszyngtonie (USA) I Światowy Kongres Immunologiczny. Był on praktycznie niedostępny dla polskich immunologów. Organizatorzy przedstawili jednak ofertę dla młodych badaczy z różnych krajów i kontynentów obejmująca pokrycie kosztów podróży, pobytu w USA, opłatę zjazdową i kieszonkowe (\$20) na osobę. Miałem szczęście, bo znalazłem się wśród 20 Polaków jako jedyny z Poznania, którzy uzyskali ten grant. Było to niesamowite i niezapomniane przeżycie dla

4 A. Szkaradkiewicz, W. Kiczka, J. Adamek, Studies on leukocyte migration inhibitory factor production by T lymphocytes in viral hepatitis. "Digestion" 1981, 22, s. 138-143 (IF- 1.55).

W. Kiczka, A. Szkaradkiewicz, J. Flieger, Studies on natural cytotoxicity of human viral hepatitis, "Immumnol Lett" 1985, 9, s. 87-91, (IF-1.1).

6 J. Juszczyk, K. Zawilska, J. Żeromski, Toczniowe zapalenie watroby, „Pol Arch Med. Wewn” 1968, 41, s. 559-663. 
nas wszystkich i wielka szansa poznania wybitnych immunologów z całego świata. Organizatorzy celowo mieszali ludzi z różnych krajów w hotelach. Ja np. dzieliłem wspólny pokój ze znanym immunologiem szwedzkim Hansem Wigzellem, któremu zreszta pomagałem przygotować wystapienie na Kongresie.

Dr Wierzchowiecki odniósł tam duży sukces uzyskując pierwszą nagrodę w konkursie na najlepszą pracę doświadczalną w Kalifornii pt. „Immunoglobulin deposits in skin in systemic lupus erythematosus", później opublikowaną w znanym czasopiśmie ${ }^{7}$.

Następstwem powstania Polskiego Towarzystwa Immunologicznego było przyjęcie go do Międzynarodowej Unii Towarzystw Immunologicznych (IUIS). Dzięki staraniom prof. Stefana Mackiewicza nasze towarzystwo uzyskało prawo organizacji satelitarnego sympozjum IUIS. Sympozjum to odbyło się w Połczynie-Zdroju a głównym organizatorem był ówczesny asystent prof. Mackiewicza dr Andrzej Mackiewicz. W sympozjum wzięło udział szereg wybitnych immunologów z całego świata, między innymi dr Kishimoto, dr Melchers, dr Acheson i wielu innych.

W międzyczasie poznańska immunologia dojrzewała pod względem organizacyjnym. Powstał Oddział Poznański PTI, którego byłem przewodniczacym przez jedna kadencję. Mieliśmy regularne zebrania naukowe, na których gościliśmy znanych polskich immunologów, jak prof. Andrzeja Górskiego czy prof. K. Madalińskiego z Warszawy. Powstawały ad hoc zespoły badawcze jak choćby powołany przez dyrektorów szpitali nieakademickich „Uczelniano-Wojewódzki Zespół d/s. Immunologii Nowotworów", którego celem było poszukiwanie zaburzeń układu odporności w przebiegu choroby nowotworowej. Zespół miał stosunkowo skromny dorobek naukowy, ale był inspiracją i mobilizacją młodych badaczy, a ponadto owocem jego istnienia była pierwsza w Poznaniu w 1991 roku międzynarodowa konferencja immunologiczna pt. Local (in situ) Immunity in Tumor and Transplant Microenvironment, zorganizowana na terenie Międzynarodowych Targów Poznańskich z udziałem ok. 200 znanych immunologów polskich, a także z Europy i Stanów Zjednoczonych. Wśród wykładowców byli między innymi profesorzy: Pierre Burtin (Francja), Peter Wilkinson (Wielka Brytania), Theresa Whiteside (USA), Jan Bubenik (Czechy) i inni. Byłem organizatorem tej konferencji przy dużym współudziale mojej współpracowniczki, mgr biologii Krystyny Jarczewskiej.

Kolejny Ogólnopolski Zjazd Polskiego Towarzystwa Immunologicznego powołał prof. S. Mackiewicza na stanowisko prezesa Zarządu Głównego, a ja natomiast zostałem sekretarzem tegoż Zarządu. Osiagnięciem naszej kadencji było zorganizowanie wyjazdu na kolejny Kongres Światowy Immunologii w Toronto (Kanada) w 1988 roku dla 40 polskich immunologów. Było to możliwe dzięki pomocy wybitnych polskich naukowców pracujacych w Ameryce, prof. Stanisława Dubiskiego, dr Marka Zaleskiego i innych, a także kanadyjskiej Polonii, która zgodziła się gościć poszczególne osoby w swoich domach.

7 M. Wierzchowiecki, F. Quismorio, G. Friou, Immunoglobulin deposits in skin in systemic lupus erythematosusa, "Arthritis Rheum"1975, 18, s. 77-82. 
Na Zjeździe PTI w Zakopanem w 1989 roku zostałem wybrany prezesem Towarzystwa, natomiast funkcję sekretarza objął dr Maciej Krzymański, nefrolog z Poznania. Był to dla mnie trudny i ciężki okres trzyletniej kadencji. Złożyły się na to: obowiązki zawodowe i dydaktyczne w Zakładzie, wyjazd sekretarza ZG Macieja Krzymańskiego na staż kliniczny do Niemiec, brak sekretarki, osobnego telefonu itp. Miałem co prawda sekretarza technicznego dr Mirosława Górnego, ale on też był w pełni zaangażowany w działalność usługową Zakładu. Sytuacje ratowała wspomniana już mgr Krystyna Jarczewska, która w wielu sprawach praktycznie pełniła funkcję mojego zastępcy. Jej zawdzięczamy powstanie pięknego mosiężnego medalu Towarzystwa z wizerunkiem Ludwika Hirszfelda, który jest obecnie wręczany wybitnym osobistościom za zasługi dla polskiej immunologii.

Razem z Krystyną organizowaliśmy wyjazd wynajętym autokarem członków Towarzystwa na Światowy Kongres Immunologii w Berlinie Zachodnim w 1991 roku. Nie ominęły nas tam pewne przygody, jak choćby to, że niektórzy z polskich uczestników, późno zgłoszeni, nie mieli gdzie spać (przyjałłem jednego - K.M. na nocleg do mego pokoju w hotelu). Ponadto organizatorzy robili trudności z udziałem „naszych" w obradach Kongresu, bo prawie nikt nie miał opłaconego „fee” (jakoś udało mi się to załatwić). Straż graniczna nie pozwoliła nikomu z naszej grupy na wejście do Wschodniego Berlina, informując, że mamy prawo na pobyt tylko w Berlinie Zachodnim. W czasie obrad Kongresu wręczyłem po raz pierwszy medal Hirszfelda. Otrzymał go wybitny immunolog australijski prof. Gustaw Nossal za różne zasługi dla polskiej immunologii.

Po mnie stanowisko prezesa Towarzystwa objęła prof. Alicja Ryżewska z Warszawy a po niej prof. Henryk Tchórzewski z Łodzi. Nikt z naszej trójki nie chciał zostać prezesem na drugą kadencję, co najlepiej świadczyło, jak trudna i odpowiedzialna była ta zaszczytna funkcja.

W latach 1990. zostałem powołany na przewodniczącego Komitetu Immunologii Wydziału VI Polskiej Akademii Nauk. Zadaniem Komitetu było opiniowanie różnych spraw i zagadnień ogólnokrajowych związanych z immunologia, w tym propozycji nagród naukowych PAN. Sekretarzem Komitetu został mój współpracownik dr hab. Jan Sikora, który bardzo dobrze wywiązywał się z tej funkcji. Komitet liczył około 20 członków, czołowych immunologów polskich, Możliwości naszego działania były jednak ograniczone ze względu na trudności w kontaktach, jak choćby brak powszechnego dostępu do Internetu. Niemniej, funkcja ta pozwalała zwrócić uwagę szacownemu gronu członków Wydziału VI PAN na żywotne problemy polskiej immunologii. Nota bene przewodniczący komitetów uczestniczyli w plenarnych zebraniach Wydziału, odpowiadali na pytania, niekiedy przedstawiali sprawozdania z działalności.

Tymczasem zbliżało się duże wyzwanie dla polskich immunologów, bo przypadł nam zaszczyt i obowiązek organizacji w 2000 roku kolejnego 14 European Immunology Meeting właśnie w Poznaniu. Prof. Andrzej Mackiewicz został wybrany przez Zarząd Główny PTI organizatorem tego spotkania. Trzeba przyznać, że był to strzał w dziesiątkę ze względu na jego wielkie zdolności menadżerskie, rozległe znajomości i układy. Pomagaliśmy mu w tych działaniach, tzn. prof. Maciej Kurpisz, kierownik 
Zakładu Immunologii Rozrodu Instytutu Genetyki Człowieka PAN, ówczesny prezes PTI i moja skromna osoba.

Spotkanie Europejskie było ze wszech miar udane. Uczestniczyło w nim około 1000 immunologów z całej Europy. Dorobek naukowy Spotkania został wydany drukiem jako osobna monografia ${ }^{8}$. Nie brakowało kłopotów logistycznych jak sale obrad, transport czy zakwaterowanie. Miejscem obrad był Zamek a nawet Opera poznańska9?.

Ukazał się z okazji Spotkania numer kultowego czasopisma "Immunology Today" ze wstępnym artykułem powitalnym Andrzeja Mackiewicza ${ }^{10}$. Spotkanie szczęśliwie dobiegło końca, wróciliśmy do codziennej pracy. Przed poznańską immunologia pojawiły się jednak nowe wyzwania i trudności. W kraju powstały nowe podspecjalizacje - immunologia kliniczna dla lekarzy i immunologia medyczna dla biologów, farmaceutów, analityków medycznych itp. Brakowało specjalistów i miejsc szkoleń dla młodych kandydatów. Kilku z nas, starszych, uzyskało wprawdzie tytuł specjalisty na drodze tzw. „szybkiej ścieżki”, ale była to kropla w morzu potrzeb.

Niektórzy koledzy, dotąd uważani za immunologów, związali się z innymi specjalnościami jak onkologia, patomorfologia, genetyka a także różne dyscypliny kliniczne jak pediatria, interna, ginekologia czy choroby zakaźne.

Nie było w Poznaniu akademickiej Katedry Immunologii jako ośrodka referencyjnego i szkoleniowego. Potrzebę powołania tej katedry w naszej Alma Mater widział i rozumiał kierownik Katedry Patomorfologii prof. Przemysław Gabryel. Poczatkowo zgodził się na przekształcenie Pracowni Immunopatologii Katedry w Zakład, a następnie poparł utworzenie Katedry Immunologii pomimo odłaczenia tej jednostki organizacyjnej od Katedry Patomorfologii, odejścia grona wartościowych pracowników i oporu niektórych starszych patomorfologów. Powstaniu Katedry towarzyszyło uzyskanie dla niej nowych pomieszczeń w budynku przy ul. Rokietnickiej, dzięki poparciu byłych i ówczesnych władz Uczelni (Rektorzy prof. prof. Antoni Pruszewicz, Grzegorz Bręborowicz).

Nie wiadomo dlaczego, ale na frontowej okładce „Immunology Today” zamiast Poznania pokazano widok panoramy Gdańska. Widocznie redakcja uznała, że Gdańsk jako byłe hanzeatyckie miasto jest bliższe przeciętnemu Europejczykowi niż Poznań...

W pomieszczeniach przeprowadzono gruntowny remont, zakupiono nowe wyposażenie laboratoriów po uzyskaniu dotacji z Fundacji na Rzecz Nauki Polskiej. Po przeprowadzce odbyło się uroczyste otwarcie Katedry w nowej lokalizacji w obecności prezesa Fundacji prof. Macieja Żylicza i władz Uczelni. Zostałem powołany na kierownika tej Katedry, którą kierowałem do czasu przejścia w stan spoczynku tzn. do

8 Progress in Basic and Clinical Immunology, A. Mackiewicz, M. Kurpisz, J. Żeromski, ed., "Adv Exp Med. Biol", vol. 495, 2001 Kluwer/Plenum Publ [Proc of 14th European Immunology Meeting (EFIS 2000), Sept 23-27 2000, Poznań, Poland].

9 Jako współprzewodniczący sesji immunologii nowotworów, siedziałem pierwszy i ostatni raz w życiu - na scenie Opery!

10 A. Mackiewicz, Immunology in Poland, "Immunol Today" 2000, 21, s. 415-416. 
2008 roku. Po mnie kierownictwo Katedry objał mój wychowanek dr hab. med. Grzegorz Dworacki. W międzyczasie zostałem powołany na koordynatora ogólnopolskiego trzyletniego programu badawczego pt. „Opracowanie, doskonalenie i wdrożenie wysoko specjalistycznych procedur diagnostycznych w chorobach o podłożu immunologicznym", finansowanego przez Ministerstwo Nauki i Szkolnictwa Wyższego Uczestniczyły w nim 32 ośrodki z całego kraju. Były to ciekawe ale i trudne lata, w czasie których organizowaliśmy spotkania sprawozdawcze, sympozja naukowe (vide „Standaryzacja w immunologii", Poznań-Kiekrz 2007 i Poznań 2008) z mobilizacją do tworzenia i wdrażania konkretnych procedur diagnostycznych. Dzielnie pomagała mi w tych działaniach organizacyjnych sekretarz Programu mgr Agnieszka Pluto-Pradzyńska.

Tymczasem do immunologów zaczęli zgłaszać się chorzy wymagający natychmiastowej pomocy lekarskiej. Pamiętam, jak do naszej jednostki organizacyjnej przyszedł mężczyzna w wieku około 40 lat z Gorzowa Wielkopolskiego z rozpoznaniem tzw. pospolitego zmiennego niedoboru odporności (CVID) i z objawami narastającej ostrej infekcji górnych dróg oddechowych. Prosił o niezwłoczne podanie mu preparatu immunoglobulin (Ig), bo tylko to, na podstawie jego uprzednich doświadczeń, może uratować mu życie. Było to trudne dla nas zadanie, nie mieliśmy ani możliwości podania ani drogiego leku. Kilka klinik odmówiło, w końcu uzyskaliśmy zgodę na podanie Ig temu choremu w Klinice Pulmonologii.

Poważne problemy związane $\mathrm{z}$ immunologia pojawiły się u pacjentów w wieku rozwojowym, tzn. u dzieci we wczesnym okresie życia, z podejrzeniem różnorodnych wrodzonych, ale także nabytych, niedoborów odporności. To wyzwanie podjęła i pomyślnie realizuje prof. Anna Bręborowicz z zespołem, kierująca obecnie Kliniką Pneumonologii, Alergologii Dziecięcej i Immunologii Klinicznej i współpracująca z Centrum Zdrowia Dziecka w Warszawie. W odniesieniu do nabytych niedoborów odporności u dzieci ważną rolę odegrała dr hab. Aleksandra Szczawińska-Popłonyk z tejże Kliniki oraz adiunkt Katedry Immunologii dr med. Husam Samara. Ten ostatni opracował ilościowy algorytm oparty na oznaczeniach subpopulacji limfocytów przy użyciu szerokiego panelu przeciwciał monoklonalnych i cytometrii przepływowej, pozwalający na precyzyjne określenie przyczyny objawów zaburzeń odporności u dziecka, zwłaszcza w połączeniu z oznaczeniem ilościowym, podklas IgG.

\section{Współpraca z zagranicą}

Immunolodzy poznańscy mieli liczne wartościowe kontakty z wieloma naukowcami i ośrodkami zagranicznymi o profilu immunologicznym. Znalazło to odbicie w częstych wyjazdach szkoleniowych młodszych kolegów, przyjazdach znanych immunologów do naszego miasta i także $\mathrm{w}$ organizacji szeregu konferencji czy sympozjów o zasięgu międzynarodowym. O kilku z nich jak "Tumor and transplant local (In situ) immunity", międzynarodowym sympozjum w Połczynie-Zdroju czy o European Immunology Meeting była już mowa wcześniej. Dzięki kontaktom 
prof. Andrzeja Mackiewicza odbyły się dwa inne międzynarodowe sympozja w Poznaniu pod patronatem Nowojorskiej Akademii Nauk.

Natomiast prof. Maciej Kurpisz od 2000 roku współpracuje z Katedra Immunologii i Alergologii lwowskiego Uniwersytetu Medycznego, czego owocem były trzy habilitacje ukraińskich kolegów i liczne kursy doszkalające w różnych ośrodkach ukraińskich prowadzone przez Macieja Kurpisza dla lekarzy z zakresu niepłodności na tle immunologicznym. Wyrazem uznania dla prof. Kurpisza było nadanie mu w 2011 roku przez Senat Uniwersytetu Medycznego we Lwowie doktoratu honoris causa, a akże tytułu honorowego patofizjologa Ukrainy.

\section{Wnioski}

W podsumowaniu należy stwierdzić, że grono poznańskich immunologów położyło duże zasługi - organizacyjne, naukowe i dydaktyczno-szkoleniowe - dla rozwoju polskiej immunologii. Warto tu wymienić nazwiska i zasługi profesorów, którzy wnieśli swój istotny wkład.

Sprawy organizacyjne

- Powstanie Polskiego Towarzystwa Immunologicznego (PTI) - Stefan Mackiewicz,

- Pełnienie funkcji prezesa PTI - Stefan Mackiewicz, Jan Żeromski, Maciej Kurpisz, Andrzej Mackiewicz

- Udział w powstaniu osobnej specjalności (immunologii klinicznej) - Maciej Kurpisz, Jan Żeromski,

- Organizacja Europejskiego Spotkania Immunologów w Poznaniu - Andrzej Mackiewicz, Maciej Kurpisz, Jan Żeromski,

- Współpraca z zagranica - Andrzej Mackiewicz, Maciej Kurpisz, Jan Żeromski

Sprawy naukowe

- Powstanie szczepionki i jej wdrożenie w leczeniu czerniaka - Andrzej Mackiewicz

- Nowoczesna immunodiagnostyka nowotworów - Jan Bręborowicz

- Czasopisma naukowe - Irena Zimmerman - Górska

- Stworzenie i wdrożenie w Polsce nowej podspecjalności - immunologii rozrodu - Maciej Kurpisz

- Wprowadzenie i wdrożenie pojęcia odporności miejscowej w ludzkich nowotworach złośliwych - Jan Żeromski

- Określenie przyczyn immunologicznych niepłodności męskiej-Maciej Kurpisz

Publikacje zwarte:

- S. Mackiewicz, red. - Immunologia, PZWL Warszawa 1986 i 1991 (II wydanie).

- M. Kurpisz, N. Fernandez, ed.- Immunology of human reproduction. BIOS Sci Publ. Oxford 1985. 
- J. Żeromski, red. Immunopatologia Praktyczna, PZWL, Warszawa 2000.

- J, Żeromski, K. Madaliński,. J. Witkowski, red.- Diagnostyka immunologiczna w praktyce lekarskiej. Wyd. Mediton, Łódź 2017.

\section{Sprawy dydaktyczno-szkoleniowe}

- wprowadzenie nauczania immunologii dla studentów medycyny, analityki i farmacji oraz stomatologii - Krzysztof Wiktorowicz, Jan Żeromski, Jan Sikora

- kierownictwo specjalizacji z immunologii klinicznej (n=3) - Jan Żeromski

\section{Wykaz literatury:}

1. Baumann-Antczak A., Wedlock N., Bednarek J. et al., Autoimmune Addison disease and 21-hydroxylase, “Lancet 1992, II, s. 439-440.

2. Dmochowski M., Hashimoto T., Bhogal B.S. et al., Immunoblotting studies of linear IgA disease, "J Dermatol Sci" 1993a, 6, s. 194-200.

3. Juszczyk J., Zawilska K., Żeromski J., Toczniowe zapalenie watroby, „Pol Arch Med. Wewn” 1968, 41, s. 559-663.

4. Kiczka W., Szkaradkiewicz A., Flieger J., Studies on natural cytotoxicity of human viral hepatitis, "Immumnol Lett" 1985, 9, s. 87-91.

5. Kosowicz J., Gryczyńska M., Botazzo G.F., A radioimmunoassay for the detection of adrenal antibodies. "Clin Exp Immunol" 1986, 63, s. 671-679.

6. Mackiewicz A., Immunology in Poland, "Immunol Today" 2000, 21, s. 415-416.

7. Progress in Basic and Clinical Immunology, ed. A. Mackiewicz M. Kurpisz, J. Żeromski, "Adv Exp Med. Biol", vol. 495, 2001, Kluwer/Plenum Publ [Proc of 14th European Immunology Meeting (EFIS 2000), Sept 23-27 2000, Poznan, Poland].

8. Szkaradkiewicz A., Kiczka W., Adamek J., Studies on leukocyte migration inhibitory factor production by T lymphocytes in viral hepatitis, "Digestion" 1981, 22, s. 138-143.

9. Wierzchowiecki M., Quismorio F., Friou G., Immunoglobulin deposits in skin in systemic lupus erythematosusa, "Arthritis Rheum"1975, 18, s. 77-82. 